Article

\title{
Biomass Performance and Competition Effects in an Established Temperate Agroforestry System of Willow and Grassland-Results of the 2nd Rotation
}

\author{
Rüdiger Graß *, Sarah Malec and Michael Wachendorf $\mathbb{B}$ \\ Grassland Science and Renewable Plant Resources, Faculty of Organic Agricultural Science, University of Kassel, \\ Steinstraße 19, 37213 Witzenhausen, Germany; sasoma@posteo.de (S.M.); mwach@uni-kassel.de (M.W.) \\ * Correspondence: rgrass@uni-kassel.de; Tel.: +49-5542-98-1312
}

Received: 29 September 2020; Accepted: 17 November 2020; Published: 19 November 2020

\begin{abstract}
Agroforestry systems (AFSs) are promoted as environmentally friendly and climate-change-resilient cultivation systems with the potential of increasing ecosystem services. Especially under temperate climatic conditions, the implementation in agricultural practice is low so far, inter alia due to the lack of knowledge regarding longer-term effects of such systems. This study investigated biomass yields and crop development during the second rotation of an alley cropping system with willows (clone "Tordis" ((Salix schwerinii $x$ S. viminalis) $x$ S. vim.)) and grassland that was established in March 2011, as reported in a former study of the authors. Two grassland swards (white clover grass (Lolium perenne L. and Trifolium repens L.) (CG) and a diversity mixture with 32 plant species (DIV)) were proven in an intensive ( $3 / 4$ cuts per year) and extensive management system (two cuts per year). Total yield (sum of three years) of AFS increased substantially in the second rotation (year four to six after establishment of the AFS). This was particularly due to a fivefold increase in woody biomass. At the same time, yields of grassland biomass decreased slightly. Biomass of CG outperformed DIV, especially in the intensive managed systems with a dry matter (DM) yield of $18 \mathrm{t} \mathrm{ha}^{-1}$, compared to $12.6 \mathrm{tha}^{-1}$. However, AFS grassland yields were always lower than yields of reference areas with grassland in pure stand. Nevertheless, lower yields are probably caused by competition effects between woody crops and grassland. Grassland yields along transects across the grassland alleyways showed a strong decrease in the border areas in all treatments. Higher grassland yields in the alley center did not compensate yield reductions in border areas. Furthermore, the botanical composition of grassland was modified in border areas with reduced legume DM contribution and increases of both grasses and forbs. Thus, the width of grassland alleys with $9 \mathrm{~m}$ caused strong competition effects by the willows.
\end{abstract}

Keywords: alley cropping; LER; willow clone "Tordis"; yield performance

\section{Introduction}

Against the background of multiple challenges for agricultural cropping systems, like aspects of climate change and environmental conflicts such as biodiversity losses, soil erosion or nutrient leaching, the demand for innovative cropping systems is increasing [1,2]. Agroforestry systems (AFSs) are often described as an innovative, multifunctional and sustainable option for increasing several environmental benefits, e.g., soil protection, biodiversity or nutrient conservation [3-5]. Furthermore AFSs could contribute to mitigate climate change by C-sequestration [5-7] and enhance adaptation to climate change [8]. With the cultivation of woody crops for bioenergy production, they could increase the share of renewable energy production and contribute to the replacement of fossil energy resources and, thus, reduce global $\mathrm{CO}_{2}$ emissions. Furthermore, AFS have been described to achieve high biomass yields and to increase land-use efficiency $[9,10]$. 
However, the implementation of AFSs in the German agricultural practice is low so far. Besides uncertainties regarding legal aspects and opportunities of subsidy payments, the lack of knowledge regarding the long-term development of yields from both agricultural and silvicultural crops creates a substantial obstacle for farmers [11,12]. In this context, the competition for light, water and nutrients between different crops within the AFS is of major importance [5,13-15], but it is often difficult to be analyzed and explained in field experiments. However, these interactions could lead to modified yields and sward compositions within the AFS $[14,16,17]$ which in turn are important pieces of information for an assessment of AFS productivity. In particular the longer-term development of AFS regarding crop and yield development is of major interest, but only few studies exist which deal with these topics, especially under temperate conditions (e.g., References [18-21]).

In the present study, a coppice alley cropping AFS of willows and grassland was investigated. Willows were used as short-rotation coppices for bioenergy production, whereas grassland is well suited both as feedstock for energy or animal feeding. Thus, this AFS could contribute to the abovementioned aims regarding climate change (adaptation and mitigation) and environmental aspects. This AFS was established in March 2011; results of the first rotation (year one to four) were reported by Reference [22]. The main objective of this study was to assess the performance of this AFS during the second rotation (year four to six after establishing) and to understand changes in sward composition and yield development of grassland, depending on the distance to willows.

\section{Materials and Methods}

\subsection{Description of Site and Experimental Design}

The investigated AFS was established in March 2011 as a coppice alley cropping system combining willows and grassland. It is located in Lower Saxony ( $51^{\circ} 39^{\prime} 83^{\prime \prime} \mathrm{N}$ and $9^{\circ} 98^{\prime} 75^{\prime \prime} \mathrm{E}, 325 \mathrm{~m}$ a.s.l.), Central Germany. The climate at the experimental site is characterized as temperate with an average temperature of $9.2^{\circ} \mathrm{C}$ and a mean annual precipitation of $642 \mathrm{~mm}$. The predominant soil type is classified as a stagnosol, according to the FAO World reference of soil resources [23], and consists of sedimentary deposits from sandstone, siltstone and claystone [24].

The alley cropping design comprised alternating multi-rows of fast-growing willows in short rotation (3-4 year) and grassland sown in the alleyways (Figure 1). Therefore, two grassland mixtures were sown as understory types in a split-plot randomized block design between the multi-rows of shrub willow hybrids, each replicated three times. The alley cropping system covered a total area of 0.7 ha. The grassland alleyways were $9 \mathrm{~m}$ wide and $80 \mathrm{~m}$ long, and the willow stripes were $7.5 \mathrm{~m}$ wide and $80 \mathrm{~m}$ long. This corresponds to a land-use proportion of $45 \%$ for willows and $55 \%$ for grassland. Alley orientation was north-west to south-east.

Two types of grassland mixtures were established in March 2011: a grassland mixture of Lolium perenne L. and Trifolium repens L. (clover/grass, CG) with a clover proportion of $31 \%$ in the seed mixture, and a diversity-oriented grassland mixture (DIV) with 32 species and a grass proportion of $43 \%$ and a proportion of non-leguminous forbs of $41 \%$. CG and DIV plots were split into subplots of $9 \mathrm{~m}$ by $6.5 \mathrm{~m}$ size, representing different cutting regimes with (i) two cuts per year (extensive utilization) and (ii) three or four cuts per year as an intensive treatment. Overall, 12 subplots were established in each alleyway. During the 1st rotation of this AFS [1], in a few subplots, fertilization was conducted for further investigation. For this manuscript, only unfertilized subplots were analyzed. That means, each treatment was investigated with one subplot in each alleyway, which results in four investigated subplots in each alleyway. For grassland maintenance, all plots were treated with a harrow in early springtime. In spring 2015, Phleum pratense L. and Dactylis glomerata L. with $4 \mathrm{~kg} \mathrm{ha}^{-1}$ each were reseeded in all CG plots. In 2016, grasslands were fertilized with $100 \mathrm{~kg} \mathrm{ha}^{-1}$ Magnesia Kainite containing $9 \% \mathrm{~K}_{2} \mathrm{O}, 4 \% \mathrm{MgO}, 35 \% \mathrm{Na}_{2} \mathrm{O}, 9 \% \mathrm{SO}_{3}$ and $47 \% \mathrm{Cl}$, and with rock phosphate of $100 \mathrm{~kg} \mathrm{P}_{2} \mathrm{O}_{5} \mathrm{ha}^{-1}$. 


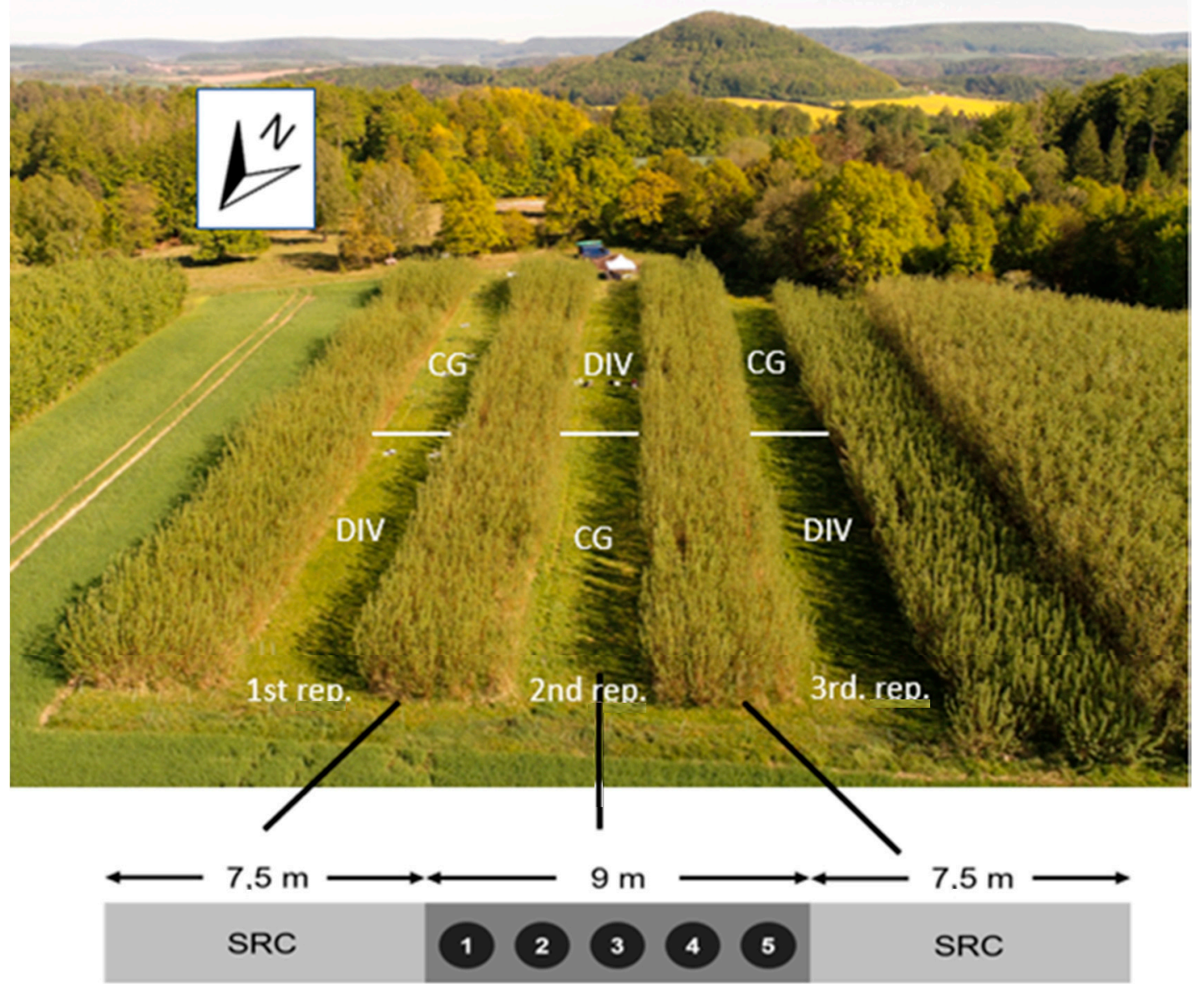

Figure 1. Alley cropping design of agroforestry system (AFS) with different grassland types $(\mathrm{CG}=$ clover/grass; DIV = diversity mixture) and willow stripes as short-rotation coppices (SRC), 3 replicates (rep. = replicate) and design of the transect structure in the AFS: 5 transect points (TPs) in grassland alleyways between the willow stripes. Reference areas of grassland and willows were located at adjacent areas.

Shrub willows were planted manually as dormant stem cuttings with 3 or 4 buds of the willow clone "Tordis" ((Salix schwerinii x S. viminalis) x S. vim.), in March 2011. A three-or-four-year rotation was chosen. A "double row" system was applied, as it is used in commercial SRC plantations and facilitates mechanical harvesting. Alternating inter-row distances were 0.75 and $1.5 \mathrm{~m}$, with a within-row spacing of $0.75 \mathrm{~m}$, to achieve a planting density of 12,000 trees per hectare. No herbicides and no fertilizers were applied. The first harvest of the willows was in February 2015 (1st rotation), and the 2nd harvest at the end of the 2nd rotation in February 2018.

For determining reference yields, both grassland mixtures were cultivated without trees, at an adjacent site, as was done with shrub willows as short-rotation coppice. Unfortunately, these grassland plots were destroyed by boars at the beginning of the 2nd rotation and were not usable for analyzation. Thus, an adjacent grassland area with a local specific sward was used as the reference grassland area for both grassland mixtures. However, this allowed a comparison with the yields of AFS without a common statistical analysis only, as these plots were not part of the randomized factorial layout of the agroforestry design. This approach was chosen as a compromise, as the concurrent cultivation of AFS and reference systems at the same site is a common problem in AFS research, due to practical management reasons [25].

Grassland biomass development in 2016 and 2017 was measured along transects in the alleys at five transect points (TPs), with TPs 1 and 5 located in a distance of $0.5-1 \mathrm{~m}$ from the willow stripes. 
The remaining TPs were equally distributed between TPs 1 and 5 . At each TP, sample plots of 0.5 by $0.5 \mathrm{~m}$ were established (Figure 1).

\subsection{Data Acquisition}

Aboveground biomass of grassland was determined in all 3 years of the 2nd rotation (2015-2017), at each harvest date, by sampling 5 randomized sampling areas of $0.25 \mathrm{~m}^{2}$ area in each subplot. Additionally, after the establishment of the transects in 2016, biomass was assessed at each of the five TPs. Grassland was cut at $50 \mathrm{~mm}$ stubble height, and herbage fresh mass was recorded. Samples of 100 to $200 \mathrm{~g}$ from each subplot were dried at $105^{\circ} \mathrm{C}$, for $48 \mathrm{~h}$, and weighed to determine herbage dry matter (DM) content. Accumulated DM yield over the period of investigation (2015-2017) was calculated as the sum of all cuts from each year. Botanical composition of grassland was assessed by manual separation of the plant functional groups, as grasses, forbs, legumes and senescent material in a subsample of $500 \mathrm{~g}$. This was conducted at every cut, for the transect points 1,3 and 5 .

For DM yield assessment of willows at the end of the 2nd rotation in February 2018, 10 plots of $2 \mathrm{~m}^{2}$ were harvested and weighted in each willow stripe. Woody biomass of each plot was chopped, and an aliquot of $200 \mathrm{~g}$ was dried at $105^{\circ} \mathrm{C}$, for determining DM content.

Pure willow and grassland stands of each treatment served as site-typical reference values, with three replications each. For determination of grassland biomass, two samples of $0.50 \mathrm{~m}^{2}$ were taken per replication, and subsequent processing and analysis were done according to the procedures in the AFS plots.

\subsection{Land Equivalent Ratio (LER)}

For assessing the productivity of AFS, the LER is a common unit of measure. The LER describes the ratio of the area under sole cropped components to the area under AFS, with its tree and grassland components needed to obtain equal amounts of yield Equation (1) [26].

$$
\text { LER }=\frac{\text { YAFS Tree }}{\text { YREFTree }}+\frac{\text { YAFS GL }}{\text { YREF GL }}
$$

where YAFS Tree ( $\left.\mathrm{t} \mathrm{DM} \mathrm{ha}{ }^{-1}\right)$ and YAFS GL $\left(\mathrm{t} \mathrm{DM} \mathrm{ha}^{-1}\right)$ are dry matter yields of trees and grassland (GL) in the AFS (Figure 2), and YREFTree and YREF GL are dry matter yields of trees and GL of the reference plots (Figure 2). For the determination of dry matter yields of trees, leaves were not considered, because short-rotation coppices in temperate climates will be harvested during winter, without leaves.

The LER was determined for the yields of each treatment (Figure 2) by both trees and grasslands. While LER $<1$ would mean that there is no productivity advantage of an AFS over a monoculture, a LER $>1$ would suggest that the production in the AFS is higher than the one in a monoculture system.

\subsection{Statistics}

The AFS experiment did not comprise reference plots of pure grassland and shrub willow stands, which is why only the AFS treatments were analyzed statistically. Treatments were assigned randomly in a split-plot design, with grassland mixture as main plot factor (M) and cutting frequency as subplot factor (C). The mixture treatments were (i) CG and (ii) DIV. Two cutting frequencies were investigated: (i) two cuts per year and (ii) three cuts per year. Treatment effects and the two-way interaction were tested by using analysis of variance based on the mixed procedure in SAS (SAS Institute Inc., Cary, NC, USA). The split-plot structure of the experiment was described by the random error terms block (B)B $\times \mathrm{M}, \mathrm{B} \times \mathrm{M} \times \mathrm{C}$ in the model. Data normality was assessed by using the UNIVARIATE procedure (SAS Institute Inc., Cary, NC, USA). Homogeneity of variance was verified through the analysis of residuals, and none of the datum required transformation. Differences between treatment means were considered statistically significant at $p<0.05$, using the LSMEANS statement (SAS). 
The effect of the position in the alleys along the grassland transect (Figure 1) on grassland yield and functional groups of grassland was calculated for each treatment, separately, due to a lack of randomization. This was determined by using a one-way ANOVA based on the GLM procedure in SAS. Comparisons of means were carried out by using Tukey's HSD post hoc test.

Shares of functional groups were determined as percentage values. For statistical analysis, these values were transformed by using the logit transformation, as suggested by Reference [27]. Values that are close to the minimum and maximum (0 and 100) achievable suggest that models in which the untransformed data were the response could lead to predicted shares of functional groups outside this range, and they might also include interactions induced by scale rather than biology (Cox and Snell, 1989). Under conditions in which levels of functional groups are low or close to $100 \%$, the absolute effects of treatments or other factors/variables tend to be smaller than at intermediate values, simply because there is less scope for response. To avoid these difficulties, the logit of functional groups (fg), defined as $\log [\mathrm{fg} /(100-\mathrm{fg})]$, was used.

\section{Results}

\subsection{Agroforestry System Yield}

AFS yield accumulated over the full three-year rotation (2015-2017) was lower in the two-cut system than in the 3/4-cut system, which was mainly caused by lower grassland yields (Figure 2), though this difference was not statistically significant (Table 1a). The yield of the site-typical pure stands of grassland (24.3 $\mathrm{t} \mathrm{DM} \mathrm{ha}^{-1}$ ) was comparable with the yields of $\mathrm{CG}_{\mathrm{AFS}}\left(23.6 \mathrm{t} \mathrm{DM} \mathrm{ha}^{-1}\right)$ and slightly higher than $\mathrm{DIV}_{\mathrm{AFS}}\left(22.6 \mathrm{t} \mathrm{DM} \mathrm{ha}^{-1}\right)$. The highest yield was achieved by willows in pure stand, with $29.6 \mathrm{t} \mathrm{DM} \mathrm{ha}^{-1}$.

Table 1. Test of fixed effects: $p$-values for (a) accumulated grassland yield in the AFS (2015-2017), as well as (b) grassland yield and (c) proportion of functional groups along the alleyway transect (2016-2017), respectively.

\begin{tabular}{|c|c|c|c|c|}
\hline \multicolumn{5}{|c|}{ (a) Accumulated Grassland Yield $\left(t \mathrm{ha}^{-1}\right)$ in the AFS } \\
\hline \multicolumn{5}{|l|}{ Effect } \\
\hline Grassland mixture (M) & 0.2014 & & & \\
\hline Cutting frequency $(\mathrm{C})$ & 0.1075 & & & \\
\hline $\mathrm{M} \times \mathrm{C}$ & 0.1652 & & & \\
\hline \multicolumn{5}{|c|}{ (b) Grassland Yield (t ha ${ }^{-1}$ ) Along the Alleyway Transect } \\
\hline Effect & 2-cut CG & 2-cut DIV & 3/4-cut CG & 3/4-cut DIV \\
\hline Transect point & $<0.001$ & 0.0074 & $<0.001$ & 0.004 \\
\hline \multicolumn{5}{|c|}{ (c) Proportion of Functional Groups (\% of DM) Along the Transect } \\
\hline Effect & 2-cut CG & 2-cut DIV & 3/4-cut CG & 3/4-cut DIV \\
\hline Grasses & 0.0178 & 0.4401 & 0.0081 & 0.0096 \\
\hline Forbs & 0.4974 & 0.0431 & 0.0185 & 0.0124 \\
\hline Legumes & 0.0179 & 0.0193 & 0.0243 & 0.0332 \\
\hline Senescent & 0.0311 & 0.0984 & 0.0032 & 0.0046 \\
\hline
\end{tabular}

Accumulated grassland yields of CG in both cutting systems were higher than in DIV, especially in the 3/4-cut system, where CG-yield was nearly $3 \mathrm{t}$ higher compared to DIV (Figure 1, not statistically significant, $p=0.2014$ ). Willow yields were similar in all AFS treatments, with an average of $14.9 \mathrm{t}$, which corresponds to a hectare yield of $33.1 \mathrm{t} \mathrm{DM}$ (willow share of $45 \%$ in the AFS; data not shown). Compared to the yield of the site-typical pure stands of grassland and willows, AFSs achieved lower yields. Pure grassland yield (28.4 $\mathrm{t} \mathrm{DM} \mathrm{ha}^{-1}$ ) was $12 \%$ and $23 \%$ higher than the total yield (grassland and willows) of $\mathrm{CG}_{\mathrm{AFS}}$ and $\mathrm{DIV}_{\mathrm{AFS}}$, respectively. The highest yield was achieved by the pure stand of willows with $29.6 \mathrm{t} \mathrm{DM} \mathrm{ha}^{-1}$. 
a) 40

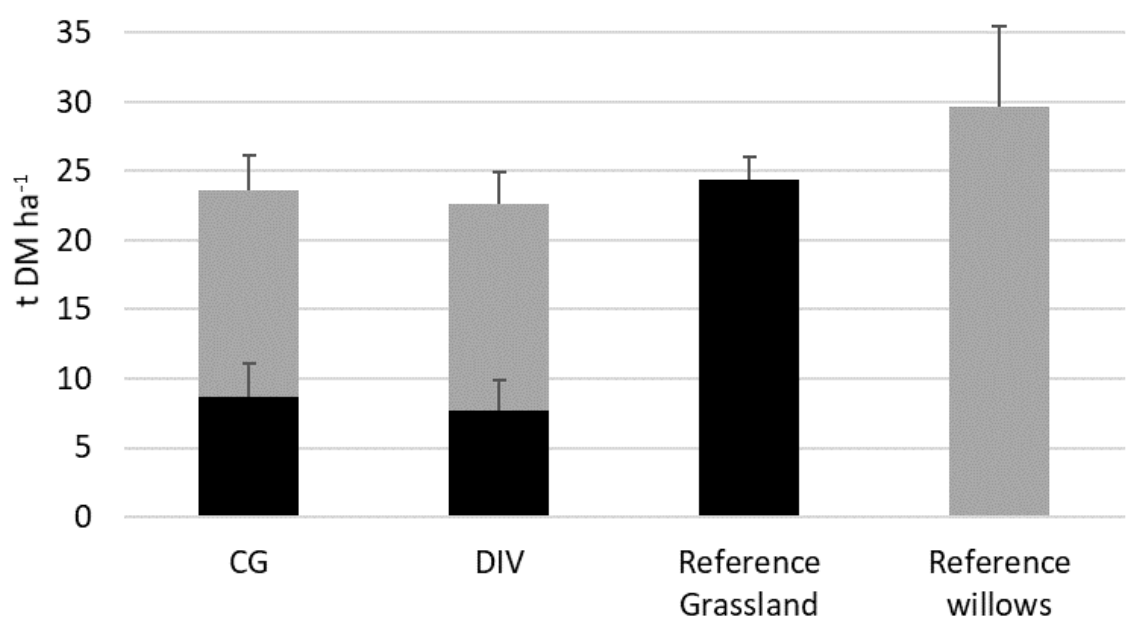

Grassland Willows

b) 40

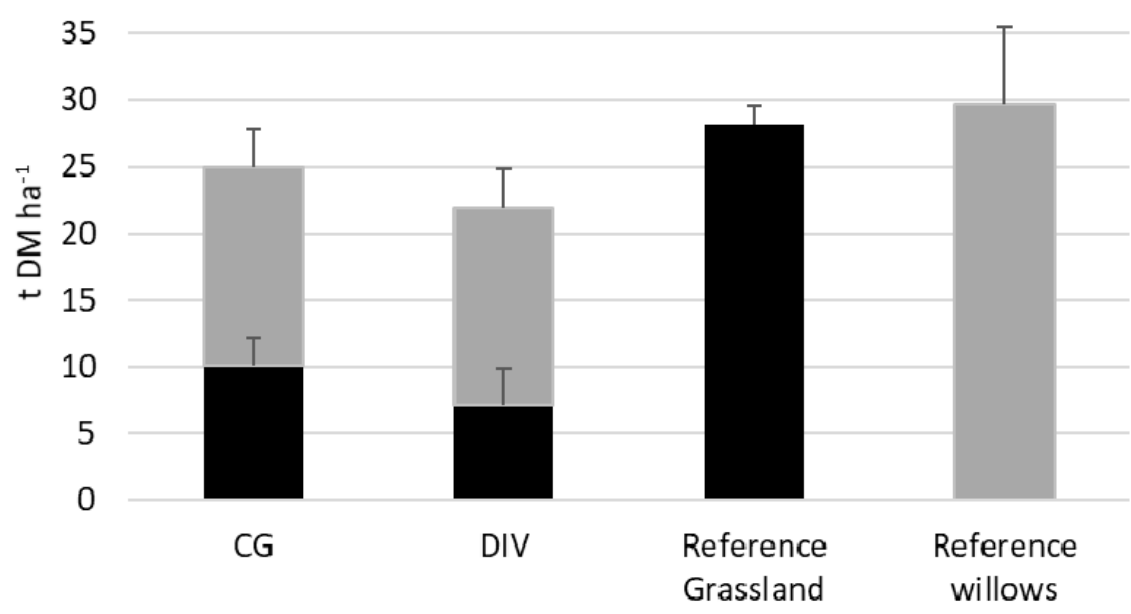

Figure 2. Total dry matter (DM) yield of AFS with different grassland types (CG = clover grass; DIV = diversity mixture) and cutting systems (a) twice and (b) 3/4 times per year, as well as of the reference grassland and willow stands (sum of 2015-2017). Bars are denominating the standard deviation. The AFS area consisted of $55 \%$ grassland and $45 \%$ willows.

\subsection{Grassland Yield along the Alleyway Transect}

The development of grassland yield was determined along a transect in the alleyways (Figure 1) and followed a uniform pattern in all treatments. TPs had a significant influence on grassland yields (Table 1b). The lowest yields were found at TPs 1 and 5 . Both TPs were adjacent to the willow stripes whereby values of TP 1 (position south-west $=\mathrm{SW}$ ) were mostly lower as TP 5 (position north-east $=\mathrm{NE}$ ) (Figure 3). However, yields increased towards the center of the transects (TP 3). 
a)

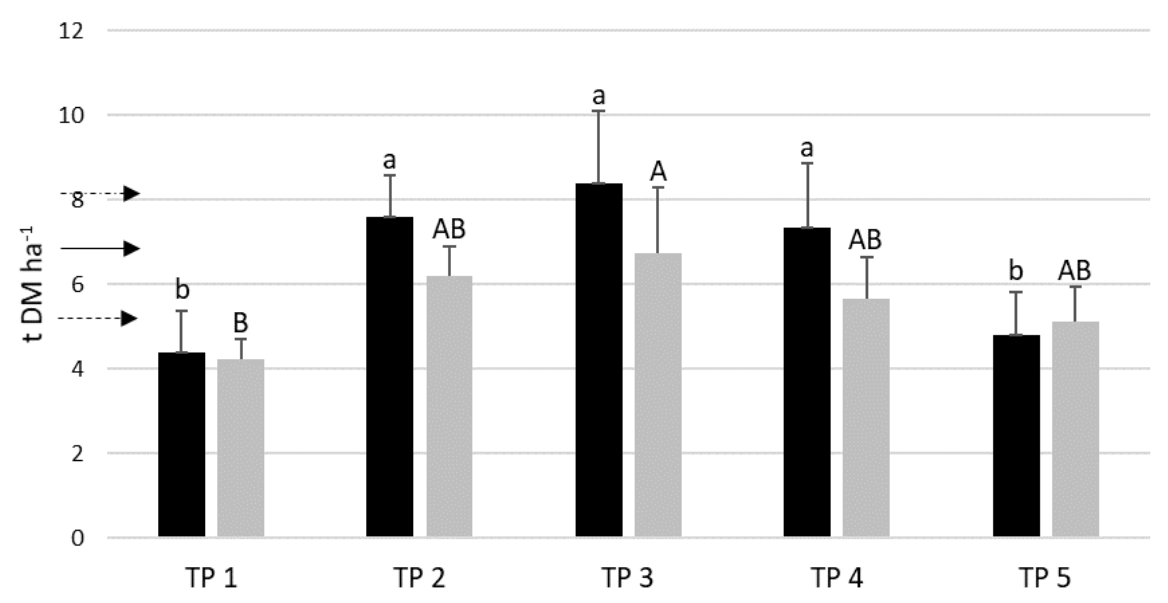

b)

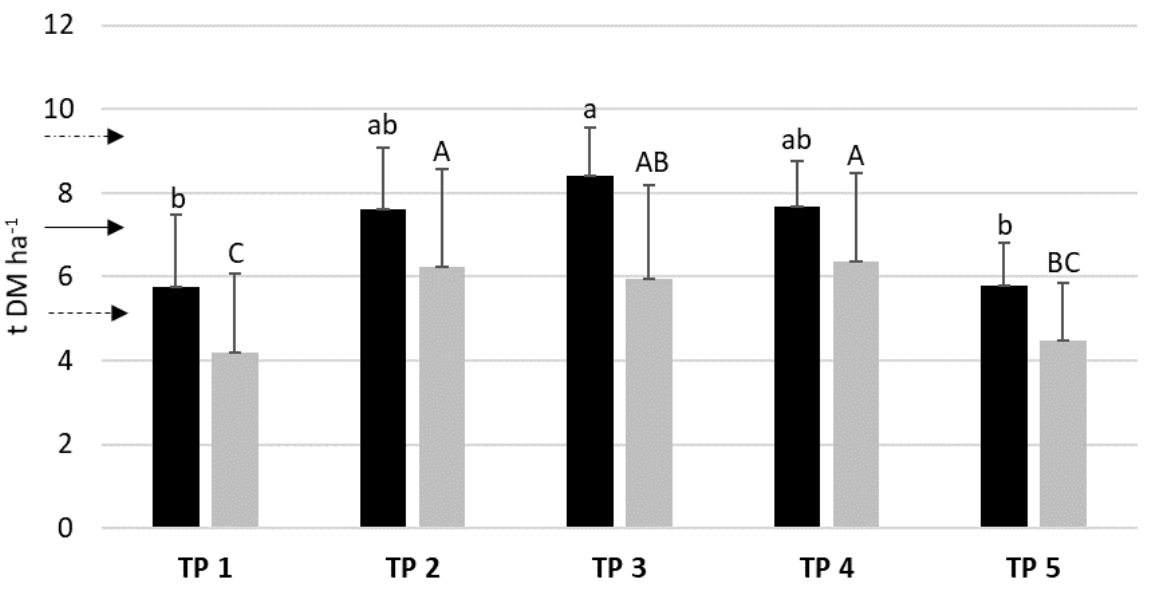

Figure 3. Annual grassland yield of clover/grass and diversity mixture along the alleyway transect (mean of 2016 and 2017) in different cutting systems: (a) twice and (b) 3/4 times per year. TP $=$ transect point; dash point arrow $=$ yield of the reference grassland area; solid arrow = mean CG yield in AFS; broken arrow $=$ mean DIV yield in AFS. Capital and lowercase letters denote significant differences between transect points in the DIV and CG AFS, respectively $(p<0.05)$. Bars are denominating the standard deviation.

The grassland yield at TP 3 of the 3/4-cut DIV treatment was similar to that of TPs 2 and 4, which was probably due to damages by mice at TP 3 .

Figure 3 also shows the total average AFS yield of CG and DIV, as well as the yield of the site-typical reference grassland. Grassland yields at TPs 1 and 5 were always lower than the average yield of CG and DIV, whereas the other TPs were equal to or above the average grassland yield of CG and DIV, independent of the cutting frequency. All treatments achieved lower yields compared to the local specific grassland yield, which served as reference.

\subsection{Functional Group Composition in the Grassland Mixtures}

Except for DIV two-cut system at TP 1, grass was always the predominant functional group, mostly with a share of more than 50\% (Figure 4). In the CG two-cut system, grass achieved at TP 3 had a more than $70 \%$ higher value, as compared to TPs 1 and 5. At the same time, the share of legumes in this treatment was significantly lower than at TPs 1 and 5, probably caused by severe mouse damage 
to legumes at TP 3. All other treatments showed similar legume proportions, with highest values at TP 3 and lowest values at TP 1, which corresponds to the south-west position of the AFS. In the DIV treatments, proportions of forbs were higher than in CG treatments, primarily as a result of the higher share of forbs in the seed mixture. Shares of senescent material were always higher at TPs 1 and 5 in the border areas of the alleyways.
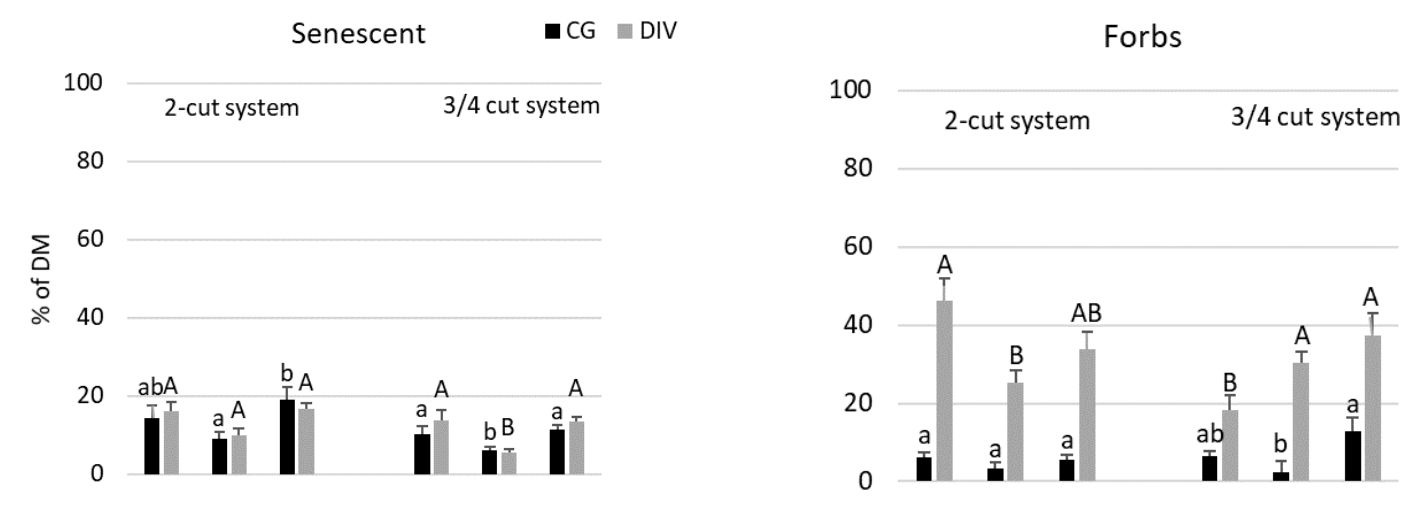

Legumes

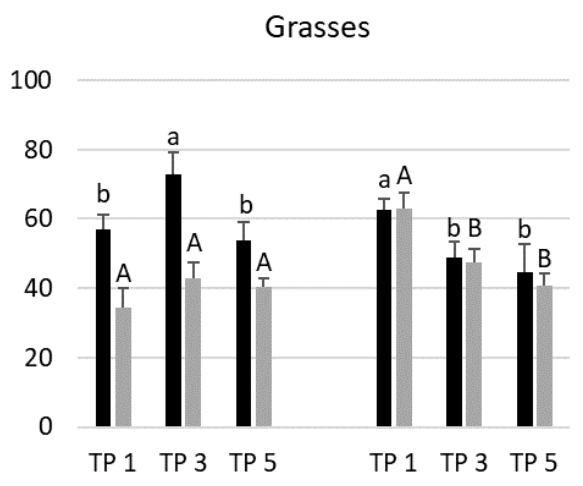

Figure 4. Proportion of functional groups in the grassland along the transect with 2 and $3 / 4$ cuts (CG = clover/grass; DIV = diversity mixture; TP = transect point). Shown are means of 2016 and 2017. Statistical information refers to the transformed scale. Different capital and lowercase letters denote significant differences between transect points in the DIV and CG mixtures, respectively $(p<0.05)$. Bars are denominating the standard deviation.

\subsection{Land Equivalent Ratio (LER)}

All investigated treatments (Figure 2) were used for calculating the LER, to determine the productivity of AFS.

DIV treatments rendered lower LER values than CG treatments (Table 2). There were no differences between the CG treatments, but the LER value of the 3/4-cut DIV treatment was lower than the value of the two-cut DIV treatment. However, all treatments obtained LER values $<1$, which means that there is no yield advantage of AFS, compared to sole cropped trees or grassland.

Table 2. Land equivalent ratio (LER) values of the investigated treatments (CG = clover grass; DIV = diversity mixture).

\begin{tabular}{ccccc}
\hline \multicolumn{5}{c}{ LER Values } \\
\hline Treatment & 2-Cut CG & 2-Cut DIV & 3/4-Cut CG & 3/4-Cut DIV \\
\hline & 0.86 & 0.82 & 0.86 & 0.75 \\
\hline
\end{tabular}




\section{Discussion}

As the interest in AFSs is increasing due to their ecological benefits [3,12], it is getting more important to gain information about the performance of these systems. While often superior yields for AFS compared to pure stand cultivations of crops, grassland or trees are reported $[3,22,28,29]$, the presented results of the second rotation of a coppice alley cropping AFS cannot confirm these advantages. In contrast, triennial yields of AFS were lower in all treatments, compared to yields of site-typical reference areas of grassland and willows as pure stands. This is further substantiated by calculated LER values, which are an indicator for land-use efficiency [26]. LER values found were between 0.75 (DIV, two cuts) and 0.86 (CG, both cutting frequencies) (Table 2); thus, for achieving the same yield as pure stands of grassland or willows, the AFS required between 14 and 25\% more area.

There exists a lasting debate about how to deal with the conflicts between the required randomization of treatments in AFS trials and the resulting dimensions, which usually would exceed the limits given in field experimentation [25,30,31]. A proper randomization of reference stands of both grasslands and willows, while simultaneously excluding any influence of the neighboring vegetation within an AFS field experiment, is practically impossible, given the common limits of resources and space. Thus, even with the replicated design of our AFS trial, which is rarely used in agroforestry research, in favor of simplicity, there remains a degree of uncertainty when it comes to yield comparisons between AFS and pure stands of both agricultural and forest plants serving as a reference. The inferiority of the investigated AFS does probably not vanish even when the width of grassland stripes is increased, as the yield in the alleyway center (i.e., TP 3) is substantially lower than that of the reference grassland.

Total yield of the investigated AFS increased substantially compared to the first rotation (started in March 2011). Willow yield in pure stand and in AFS was 29.6 and $14.9 \mathrm{t} \mathrm{DM} \mathrm{ha}^{-1}$ in the second rotation, while, in the first rotation of the same AFS, the yield was only 7 and $2.5 \mathrm{t} \mathrm{DM} \mathrm{ha}^{-1}$, respectively [22]. This is not surprising, as it is well-known that shrub willows have low growth rates in the first years after establishment [32-34]. Reference [35] reported higher growth rates of shrub willows during the second rotation, after low yields during first rotation, which further confirms our results. Higher willow yields within AFS (33.1 t DM ha $\left.{ }^{-1}\right)$ than in pure stands $\left(29.1 \mathrm{t} \mathrm{DM} \mathrm{ha}^{-1}\right)$ might. be an effect of enhanced growing conditions for willows in AFS [36]. Due to the width of $7.5 \mathrm{~m}$ of willow stripes in the investigated AFS, there are probably positive border effects, which lead to advantageous growth conditions with lower competition within willow swards, especially for daylight [20].

High growing rates of willows could strengthen competition between trees and grassland within the AFS. The average height of willows was $4.47 \mathrm{~m}$, with an average diameter at breast height of $2.9 \mathrm{~cm}$ (data not shown). Several studies $[13,37,38]$ stated that competition for resources (water, light and nutrients) is the main reason for decreased yields of agricultural crops in AFS, especially under temperate climate [39]. These findings are confirmed by the present investigation of a transect with five TPs evenly distributed in the grassland alleyways of AFS, where significantly lower yields were determined in the border areas (TPs 1 and 5). These are the areas where competition for light, water and nutrients between trees and understory vegetation is most pronounced [38,40]. Several studies [21,41] described significantly lower yields of winter wheat in proximity to the trees of an AFS, as a result of competition. However, these lower yields were compensated by higher yields in the center of the alleyways of arable crops. Thus, no difference in the total wheat yield between AFS and a sole cropped reference area was detected. In our experiment, both in the central (TP 3) and intermediate areas (TPs 2 and 4) of the grassland alleyways, higher yields were found, as compared to the border areas; however, this did not compensate the lower yields in the border areas. In contrast, yields at all TPs were almost always lower compared to yields of the site-typical grassland, indicating that, during the second rotation, the fast and high grown trees competed severely against the grassland plants throughout the alleyways.

Another reason for lower yields in the border areas of alleyways may be the altered sward composition of grassland. The lower legume contribution may be a consequence of shadow effects of 
willows, which inhibit the growth of the white clover through a reduced radiation [17], putting it at an unfavorable competitive position. As the investigated AFS did not receive any nitrogen fertilizer, atmospheric nitrogen fixation of legumes was the major source of nitrogen for the growth of plants. Thus, as less legumes lead to lower rates of nitrogen fixation [42,43], it can be assumed that, besides the competition for water and nutrients, light deficiency was a major cause for the declining yields in border areas. Furthermore, higher shares of senescent material have contributed to yield reduction due to a reduced photosynthetic active biomass at these sites.

Consequently, the different share of legumes in the two grassland seed mixtures used in the present trial has also brought about yield differences between CG and DIV grasslands. While perennial ryegrass and white clover were the main components of CG, which are well-known as high productive grassland species, especially under temperate European climate conditions [44-46], the DIV seed mixture, which is typically used to enhance floristic biodiversity, contained no white clover, but was composed by 32 species, which were generally not improved by plant breeder and, thus, of lower productivity.

Establishment and regrowth of DIV after cutting is mostly slow [47], which also explains the lower productivity and biomass yields. Furthermore, these seed mixtures are well suited for extensive utilization; in the presented field trial, triennial biomass yield of DIV in the two-cut system was nearly $1.2 \mathrm{t} \mathrm{DM} \mathrm{ha}{ }^{-1}$ higher, as compared to the intensive 3/4-cut system (Figure 2). By contrast, CG achieved in the $3 / 4$ cut system $2.3 \mathrm{t}$ more biomass, as compared to the two-cut system, which confirms the high productivity of CG in permanent intensive cultivation systems [46].

\section{Conclusions}

The following conclusions can be drawn from the present study:

Triennial yield of the investigated AFS was higher during the second compared to first rotation [22], as a consequence of a substantial increase in willow yield. Nevertheless, yield of site-typical reference areas (grassland and willows in pure stands) was higher compared to AFS. Thus, the frequently described overyielding of AFS was not confirmed in the present study. Grassland in AFS performed on a low level due to competition by willows that was particularly severe in the border areas of the alleyways, where only a low proportion of white clover was found.

Overall, AFS yield was lower compared to pure stands of grasslands and willows. However, as the reference plots were not integrated into the AFS trial, a comparison of AFS yields with reference stands within a common statistical model was not possible; thus, results must be interpreted with caution.

Author Contributions: R.G. and M.W. conceived the idea of the study; S.M. and R.G. conducted the field work; S.M., R.G. and M.W. processed and analyzed the data; R.G. and M.W. wrote the manuscript. All authors have read and agreed to the published version of the manuscript.

Funding: This work was funded by the German Ministry of Education and Research (BMBF) as a part of the research project SIGNAL (Sustainable intensification of agriculture through agroforestry) within the Framework Program BONARES (Soil as a sustainable resource for the bioeconomy).

Acknowledgments: The authors thank Wolfgang Funke and Andrea Gerke for their technical support in conducting field trials and Eike Rommelfanger for support in statistical analysis. Furthermore, the authors thank the reviewers for their valuable comments, which contributed to the improvement of this manuscript.

Conflicts of Interest: The authors declare no conflict of interest.

\section{References}

1. Smith, J.; Pearce, B.D.; Wolfe, M.S. Reconciling productivity with protection of the environment: Is temperate agroforestry the answer? Renew. Agric. Food Syst. 2013, 28, 80-92. [CrossRef]

2. Dinesh, D.; Campbell, B.; Bonilla-Findji, O.; Richards, M. 10 Best bet Innovations for Adaptation in Agriculture: A Supplement to the UNFCCC NAP Technical Guidelines: CCAFS Working Paper No. 215; CGIAR Research Program on Climate Change, Agriculture and Food Security (CCAFS): Wageningen, The Netherlands; Available online: www.ccafs.cgiar.org (accessed on 23 August 2020). 
3. Quinkenstein, A.; Wöllecke, J.; Böhm, C.; Grünewald, H.; Freese, D.; Schneider, B.U.; Hüttl, R.F. Ecological benefits of the alley cropping agroforestry system in sensitive regions of Europe. Environ. Sci. Policy 2009, 12, 1112-1121. [CrossRef]

4. Tsonkova, P.; Böhm, C.; Quinkenstein, A.; Freese, D. Ecological benefits provided by alley cropping systems for production of woody biomass in the temperate region: A review. Agrofor. Syst. 2012, 85, $133-152$. [CrossRef]

5. Jose, S.; Bardhan, S. Agroforestry for biomass production and carbon sequestration: An overview. Agrofor. Syst. 2012, 86, 105-111. [CrossRef]

6. Lorenz, K.; Lal, R. Soil organic carbon sequestration in agroforestry systems. A review. Agron. Sustain. Dev. 2014, 34, 443-454. [CrossRef]

7. IPCC 2019.: Summary for Policymakers. In: Climate Change and Land: An IPCC Special Report on Climate Change, Desertification, Land Degradation, Sustainable Land Management, Food Security, and Greenhouse Gas Fluxes in Terrestrial Ecosystems. Shukla, P.R.,Skea, J., Buendia, E.C., Masson-Delmotte, V., Pörtner, H.-O., Roberts, D.C., Zhai, P., Slade, R., Connors, S., van Diemen, R., et al., Eds. Available online: https://www.ipcc.ch/srccl/ (accessed on 4 September 2020).

8. Hernández-Morcillo, M.; Burgess, P.; Mirck, J.; Pantera, A.; Plieninger, T. Scanning agroforestry-based solutions for climate change mitigation and adaptation in Europe. Environ. Sci. Policy 2018, 80, 44-52. [CrossRef]

9. Fagerholm, N.; Torralba, M.; Burgess, P.J.; Plieninger, T. A systematic map of ecosystem services assessments around European agroforestry. Ecol. Indic. 2016, 62, 47-65. [CrossRef]

10. Paul, C.; Weber, M.; Knoke, T. Agroforestry versus farm mosaic systems-Comparing land-use efficiency, economic returns and risks under climate change effects. Sci. Total. Environ. 2017, 22-35. [CrossRef]

11. Böhm, C.; Tsonkova, P.; Zehlius-Eckert, W. Wie Können Agroforstsysteme Praktikabel in Das Deutsche Agrarförderrecht Eingebunden Werden. 5. Forum Agroforstsysteme, Cottbus-Senftenberg 2016, 5, 7-16.

12. Tsonkova, P.; Mirck, J.; Böhm, C.; Fütz, B. Addressing farmer-perceptions and legal constraints to promote agroforestry in Germany. Agrofor. Syst. 2018, 92, 1091-1103. [CrossRef]

13. Jose, S.; Gillespie, A.; Pallardy, S. Interspecific interactions in temperate agroforestry. Agrofor. Syst. 2004, 237-255. [CrossRef]

14. Nurk, L.; Graß, R.; Wachendorf, M. Productivity at the tree-crop interface of a young willow-grassland alley cropping system. Agrofor. Syst. 2016, 92, 71-83. [CrossRef]

15. Coussement, T.; Maloteau, S.; Pardon, P.; Artru, S.; Ridley, S.; Javaux, M.; Garré, S. A tree-bordered field as a surrogate for agroforestry in temperate regions: Where does the water go? Agric. Water Manag. 2018, 210, 198-207. [CrossRef]

16. Gillespie, A.R.; Jose, S.; Mengel, D.B.; Hoover, W.L.; Pope, P.E.; Seifert, J.R.; Biehle, D.J.; Stall, T.; Benjamin, T.J. Defining competition vectors in a temperate alley cropping system in the midwestern USA: 1. Production physiology. Agrofor. Syst. 2000, 48, 25-40. [CrossRef]

17. Ehret, M.; Graß, R.; Wachendorf, M. The effect of shade and shade material on white clover/perennial ryegrass mixtures for temperate agroforestry systems. Agrofor. Syst. 2015, 89, 557-570. [CrossRef]

18. Gruenewald, H.; Brandt, B.K.; Schneider, B.U.; Bens, O.; Kendzia, G.; Hüttl, R.F. Agroforestry systems for the production of woody biomass for energy transformation purposes. Ecol. Eng. 2007, 29, 319-328. [CrossRef]

19. Gamble, J.D.; Johnson, G.; Sheaffer, C.C.; Current, D.A.; Wyse, D.L. Establishment and early productivity of perennial biomass alley cropping systems in Minnesota, USA. Agrofor. Syst. 2013, 88, 75-85. [CrossRef]

20. Lamerre, J.; Schwarz, K.-U.; Langhof, M.; Von Wühlisch, G.; Greef, J.-M. Productivity of poplar short rotation coppice in an alley-cropping agroforestry system. Agrofor. Syst. 2015, 89, 933-942. [CrossRef]

21. Kanzler, M.; Böhm, C.; Mirck, J.; Schmitt, D.; Veste, M. Microclimate effects on evaporation and winter wheat (Triticum aestivum L.) yield within a temperate agroforestry system. Agrofor. Syst. 2019, 93, 1821-1841. [CrossRef]

22. Ehret, M.; Bühle, L.; Graß, R.; Lamersdorf, N.; Wachendorf, M. Bioenergy provision by an alley cropping system of grassland and shrub willow hybrids: Biomass, fuel characteristics and net energy yields. Agrofor. Syst. 2014, 89, 365-381. [CrossRef]

23. IUSS Working Group WRB. World Reference Base for Soil Resources 2014, Update 2015 International Soil Classification System for Naming Soils and Creating Legends for Soil Maps; World Soil Resources Reports No. 106; FAO: Rome, Italy, 2015; Available online: http://www.fao.org/3/i3794en/I3794en.pdf (accessed on 17 August 2020). 
24. Hartmann, L.; Richter, F.; Busch, G.; Ehret, M.; Jansen, M.; Lamersdorf, N. Establishment of short rotation coppices in the South of Lower Saxony and in Central Thuringia in the context of the BEST-research framework-Site characteristics and initial biomass production. Forstarchiv 2014, 85, 134-150.

25. Dupraz, C. Adequate design of control treatments in long term agroforestry experiments with multiple objectives. In Forestry Sciences; Springer Science and Business Media LLC: Cham Switzerland, 1999; Volume 60, pp. 35-48.

26. Mead, R.; Willey, R.W. The Concept of a 'Land Equivalent Ratio' and Advantages in Yields from Intercropping. Exp. Agric. 1980, 16, 217-228. [CrossRef]

27. Connolly, J. Developing Multisite Dynamic Models of Mixed Species Plant Communities. Ann. Bot. 2001, 88, 703-712. [CrossRef]

28. Graves, A.R.; Burgess, P.J.; Palma, J.H.N.; Herzog, F.; Moreno, G.; Bertomeu, M.; Dupraz, C.; Liagre, F.; Keesman, K.; Van Der Werf, W.; et al. Development and application of bio-economic modelling to compare silvoarable, arable, and forestry systems in three European countries. Ecol. Eng. 2007, 29, 434-449. [CrossRef]

29. Wilson, M.H.; Lovell, S.T. Agroforestry-The Next Step in Sustainable and Resilient Agriculture. Sustainability 2016, 8, 574. [CrossRef]

30. Stamps, W.T.; Linit, M.J. The problem of experimental design in temperate agroforestry. Agrofor. Syst. 1998, 44, 187-196. [CrossRef]

31. Huxley, P.A. Agroforestry experimentation: Separating the wood from the trees? Agrofor. Syst. 1987, 5, 251-275. [CrossRef]

32. Aylott, M.J.; Casella, E.; Tubby, I.; Street, N.R.; Smith, P.; Taylor, G. Yield and spatial supply of bioenergy poplar and willow short-rotation coppice in the UK. New Phytol. 2008, 178, 358-370. [CrossRef]

33. Dimitriou, I.; Mola-Yudego, B.; Aronsson, P. Impact of Willow Short Rotation Coppice on Water Quality. BioEnergy Res. 2012, 5, 537-545. [CrossRef]

34. Stork, M.; Schulte, A.; Murach, D. Large-scale fuelwood production on agricultural fields in mesoscale river catchments-GIS-based determination of potentials in the Dahme river catchment (Brandenburg, NE Germany). Biomass Bioenergy 2014, 64, 42-49. [CrossRef]

35. Sleight, N.J.; Volk, T.; Johnson, G.A.; Eisenbies, M.H.; Shi, S.; Fabio, E.S.; Pooler, P.S. Change in Yield Between First and Second Rotations in Willow (Salix spp.) Biomass Crops is Strongly Related to the Level of First Rotation Yield. BioEnergy Res. 2015, 9, 270-287. [CrossRef]

36. Clinch, R.L.; Thevathasan, N.V.; Gordon, A.M.; Volk, T.; Sidders, D. Biophysical interactions in a short rotation willow intercropping system in southern Ontario, Canada. Agric. Ecosyst. Environ. 2009, 131, 61-69. [CrossRef]

37. Fernández, M.E.; Gyenge, J.; Licata, J.; Schlichter, T.; Bond, B.J. Belowground interactions for water between trees and grasses in a temperate semiarid agroforestry system. Agrofor. Syst. 2008, 74, 185-197. [CrossRef]

38. Mantino, A.; Volpi, I.; Micci, M.; Pecchioni, G.; Bosco, S.; Dragoni, F.; Mele, M.; Ragaglini, G. Effect of Tree Presence and Soil Characteristics on Soybean Yield and Quality in an Innovative Alley-Cropping System. Agronomy 2019, 10, 52. [CrossRef]

39. Dohn, J.; Dembélé, F.; Karembé, M.; Moustakas, A.; Amévor, K.A.; Hanan, N.P. Tree effects on grass growth in savannas: Competition, facilitation and the stress-gradient hypothesis. J. Ecol. 2013, 101, 202-209. [CrossRef]

40. Douglas, G.B.; Walcroft, A.S.; Hurst, S.E.; Potter, J.F.; Foote, A.G.; Fung, L.E.; Edwards, W.R.N.; Dijssel, C.V.D. Interactions between Widely Spaced Young Poplars (Populus spp.) and Introduced Pasture Mixtures. Agrofor. Syst. 2006, 66, 165-178. [CrossRef]

41. Winterling, A. Erträge von Winterweizen in einem Agroforstsystem zur Energieholzgewinnung im ökologischen Landbau. In Proceedings of the 14th Scientific Conference for Organic Farming, Freising, Germany, 7-10 March 2017.

42. Stagnari, F.; Maggio, A.; Galieni, A.; Pisante, M. Multiple benefits of legumes for agriculture sustainability: An overview. Chem. Biol. Technol. Agric. 2017, 4, 2. [CrossRef]

43. Grüner, E.; Wachendorf, M.; Moeckel, T. The potential of UAV-borne spectral and textural information for predicting aboveground biomass and N fixation in legume-grass mixtures. PLoS ONE 2020, 15, e0234703. [CrossRef]

44. Frame, J.; Newbould, P. Herbage production from grass/white clover swards. Forage Legumes 1984, 16, 15-35. 
45. Andrews, M.; Scholefield, D.; Abberton, M.; McKenzie, B.; Hodge, S.; Raven, J. Use of white clover as an alternative to nitrogen fertiliser for dairy pastures in nitrate vulnerable zones in the UK: Productivity, environmental impact and economic considerations. Ann. Appl. Biol. 2007, 151, 11-23. [CrossRef]

46. Peyraud, J.L.; Le Gall, A.; Luescher, A. Potential food production from forage legume-based-systems in Europe: An overview. Irish J. Agric. Food Res. 2009, 48, 115-135.

47. DeHaan, L.R.; Weisberg, S.; Tilman, D.; Fornara, D. Agricultural and biofuel implications of a species diversity experiment with native perennial grassland plants. Agric. Ecosyst. Environ. 2010, 137, 33-38. [CrossRef]

Publisher's Note: MDPI stays neutral with regard to jurisdictional claims in published maps and institutional affiliations.

(C) 2020 by the authors. Licensee MDPI, Basel, Switzerland. This article is an open access article distributed under the terms and conditions of the Creative Commons Attribution (CC BY) license (http://creativecommons.org/licenses/by/4.0/). 